\title{
PERSPEKTIF KYAI PONDOK PESANTREN SALAF DI JAWA TENGAH MENGENAI ZAKAT BERFUNGSI SEBAGAI PENGURANG PAJAK PENGHASILAN
}

\author{
Nur Rofiq, Wahyu Prabowo \\ 1,2 Prodi Hukum Universitas Tidar, Indonesia \\ Email: nurrofiq726@gmail.com¹,wahyuprabowo2019@gmail.com²
}

DOI: $10.29313 /$ tjpi.v8i2.5226

Accepted: October 15th, 2019. Approved: November 29th, 2019. Published: December 11th, 2019

\begin{abstract}
Paying alms is an obligation for Moslem who has completed the requirement and pillars. While paying income tax $(P P h)$ is an obligation for Moslem as citizens. Therefore, Moslem bear double taxes that have to be paid. Does this research aim to prove how is the perspective of Kyai of Salaf's Islamic Boarding School in Central Java relates to alms which has function to decrease the income tax? This research uses descriptive-qualitative. The respondents are Kyai of Salaf's Islamic Boarding School in Central Java. The data collected through observation, interviews, and documentation. Data analysis uses synthesis descriptive method. This research shows the perspective of Kyai of Salaf's Islamic Boarding School in Central Java generally agree that the paid of alms by Moslem through BAZNAS (National Alms Agency) has a function to decrease the income tax (PPh), because the alms of profession or income can be for all professionalism skills or job, the job can be in individual or group or other organizations that have halal income and already have reached minimum, so they have to pay the alms (nishab). Meanwbile the almsgiving distribution, better it is diverted from sometbing consumptive to productive. Then the management of almsgiving uses transparent, accountable, and professional management.
\end{abstract}

Keywords: Kyai of Salaf's Islamic Boarding School; Alms; Income Tax.

\begin{abstract}
Abstrak
Membayar zakat merupakan kewajiban bagi umat Islam yang sudah memenubi syarat dan rukunnya. Sedangkan membayar Pajak Penghasilan (PPh) merupakan kewajiban umat Islam sebagai warga negara. Dengan demikian, umat Islam menanggung beban ganda (double tax) yang wajib dilaksanakan. Penelitian ini bertujuan untuk membuktikan bagaimana Perspektif Kyai Pondok Pesantren Salaf di Jawa Tengah Mengenai Zakat Berfungsi Sebagai Pengurang Pajak Penghasilan? Penelitian ini memakai metode deskriptif kualitatif. Responden penelitiannya Kyai Pondok. Pesantren Salaf di Jawa Tengah. Pengumpulan data dilakukan dengan observasi, wawancara dan dokumentasi. Untuk menganalisis data digunakan metode deskriptif sintesis. Penelitian ini menunjukkan bahwa secara umum perspektif Kyai Pondok Pesantren Salaf di Jawa Tengah sepakat jika zakat yang dibayarkan oleh umat Islam lewat BAZNAS dapat berfungsi sebagai pengurang Pajak Penghasilan (PPh), karena zakat profesi atau penghasilan merupakan zakat yang dapat dikenakan kepada setiap keablian tertentu atau pekerjaan tertentu yang sifatnya profesionalitas, bisa juga pekerjaan tersebut dikerjakan secara sendiri atau dilakukan secara bersamasama maupun lembaga lain yang dapat menghasilkan pendapatan yang halal serta sudah mencapai tenggat minimal, maka berkewajiban mengeluarkan zakat (nishab). Sedangkan penyaluran zakat sebaiknya dialibkan dari bentuk konsumtif ke dalam bentuk produktif. Serta pengelolaan zakat menggunakan manajemen zakat yang transparan, akuntabel dan profesional.
\end{abstract}

Kata Kunci: Kyai Ponpes Salaf, Zakat; PPh. 


\section{PENDAHULUAN}

Pembahasan persoalan tentang penggabungan zakat dan pajak sudah lama menjadi perbincangan para ulama sejak dahulu sampai saat ini, sebab beberapa ulama ada yang berpendapat bahwa pembayaran zakat dapat dijadikan sebagai pembayaran pajak penghasilan. Tetapi ada pula yang tidak sependapat dengan hal itu. Oleh sebab itu, maka umat Islam dikenai dualisme pemungutan (double taxs), artinya sebagai seorang pribadi atau badan menjadi wajib membayar bayar (taxs payers) dan berkewajiban juga membayar zakat (murzaki). Hal ini sesuai dengan ("UU 38 Tahun 1999 tentang zakat bisa berfungsi sebagai Pengurang Pajak Penghasilan (PPh)," n.d.) mengenai pengelolaan zakat, serta menjadi wajib pajak sesuai ("UU No. 36 Tahun 2008 tentang Perubahan Keempat atas UU No. 7 Tahun 1983 tentang Pajak Penghasilan," n.d.). Dari kedua UU tersebut dinyatakan bahwa zakat dan pajak merupakan kewajiban. Jika penghasilan berasal dari keahlian atau pekerjaan tertentu yang sifatnya profesionalitas dikenakan $\mathrm{PPh}$ dan zakat atau yang disebut dengan zakat profesi.

Abu Zahrah dalam (Doa, 2008) menyatakan bahwa pajak itu sampai sekarang tidak memiliki nilai-nilai khusus yang dapat memberikan jaminan sosial. Sedangkan zakat dapat memenuhi tuntutan pajak, akan tetapi pajak tidak dapat memenuhi tuntutan zakat, karena pajak tidak menanggulangi kebutuhan fakir miskin. Oleh sebab itu zakat dan pajak sebagai sesuatu yang berbeda dan tidak dapat disatukan.

Sedangkan menurut Masdar Farid Mas'ud (Mas'ud, 2010) mengatakan bahwa pemisahan lembaga zakat dan pajak merupakan kebijakan yang sesat dan menyesatkan, sebab konsep zakat merupakan konsep pajak. Zakat sebagai ruhnya dan pajak sebagai badannya. Demikian pula orang yang akan membayar pajak wajib diniati juga untuk menunaikan zakat. Dengan begitu, maka istilah double tax yang menjadi alasan bagi umat Islam untuk enggan membayar zakat dapat teratasi, karena zakat dan pajak merupakan dua kewajiban yang bisa disatukan menjadi satu walaupun berasal dari akar kewajiban yang oleh ulama konvensional dibedakan. Dengan mengabungkan pajak dan zakat menjadi satu, berarti umat Muslim yang membayar pajak (dengan niat membayar zakat) kepada pemerintah, maka kewajiban membayar zakatmenjadi gugur .

Berdasar latar belakang tersebut, penelitian ini menitikberatkan pada pendapat para Kyai pemangku pondok pesantren salaf yang berada di wilayah Jawa Tengah tentang pengeluaran zakat dapat dijadikan sebagai pengurang pajak penghasilan. Penelitian ini berjudul: "Perspektif Kyai Pondok Pesantren Salaf Di Jawa Tengah Mengenai Zakat Berfungsi Sebagai Pengurang Pajak Penghasilan"

\section{KAJIAN TEORITIK}

\section{Kyai Pondok Pesantren Salaf}

Definisi Kyai atau Kiai adalah sebutan bagi seorang laki-laki atau benda yang sangat disakralkan dan dihormati. Menurut orang Jawa kata Kyai atau Kiai adalah sebutan bagi orang yang berjenis kelamin laki-laki yang dihormati dan dituakan maupun barang. Sedangkan bagi seseorang yang berjenis kelamin perempuan disebut Nyai. Kata Kyai atau Kiai bisa digunakan untuk menyebut ulama, pusaka, hewan, makhluk halus dan orang yang sudah meninggal dunia.

Arti salaf menurut KBBI (Kemendikbud, 2018) yaitu sesuatu atau orang yang terdahulu. Sedangakan arti salaf (آلسَّلَفْ terdahulu (nenek moyang), yang lebih tua dan lebih utama serta para pendahulu. Sedangkan menurut istilah terminologi berarti generasi pertama dan terbaik dari ummat Islam, yaitu para sahabat, tabi'in, tabi'ut tabi'in dan para imam pembawa petunjuk pada tiga generasi kurun pertama. 
Pondok pesantren salaf menurut (Hasbullah, 2001) yaitu suatu lembaga pendidikan Islam, yang di dalamnya terdapat seorang Kyai (pendidik) yang mengajar dan mendidik para santri (anak didik). Dan masjid sebagai sarana yang digunakan untuk menyelenggarakan pendidikan tersebut. Serta berdirinya pondok sebagai tempat tinggal para santri. Jadi ciri-ciri pondok pesantren yaitu adanya kyai, santri, masjid, dan pondok.

Jadi pondok pesantren salaf adalah suatu lembaga pendidikan Islam yang diselenggarakan dengan ciri-ciri seorang Kyai sebagai pendidik, santri sebagai peserta didik, masjid sebagai tempat untuk menyelenggarakan pendidikan serta adanya pondok sebagai tempat tinggal para santri yang mengikuti ajaran para salafus shalih yang terdahulu.

\section{Unsur-unsur Pokok Pondok Pesantren Salaf}

Menurut Binti Maunah (2009:18), ada lima unsur pokok dan sekaligus menjadi ciri khas pondok pesantren yaitu: 1). Kyai, sebagai pendidik, pengajar dan pengasuh, 2). Santri, sebagai pelajar yang belajar mengaji kepada kyai, 3). Masjid, sebagai sarana untuk menyelenggarakan pendidikan, shalat berjamaah dan kegitan lainnya, 4). Pondok pesantren, sebagai tempat bermukim santri, 5). Pengajian kitab kuning atau kitab klasik.

\section{Ciri-ciri Pondok Pesantren}

Menurut Abdul Munir Mulkhan (Mulkhan, 2003) ciri-ciri pesantren sebagai berikut; 1). Adanya hubungan yang akrab antar murid (santri) dengan kyai, 2). Tunduknya santri kepada kyai, 3). Hidup hemat dan sederhana benar-benar dilakukan dalam kehidupan pesantren, 4). Semangat menolong diri sendiri amat terasa kental di pesantren, 5). Jiwa tolong menolong dan suasana persaudaraan sangat mewarnai pergaulan di pesantren, 6). Disiplin sangat ditekankan dalam kehidupan pondok pesantren, 7). Berani menderita untuk mencapai sesuatu tujuan merupakan salah satu pendidikan yang diperoleh di pesantren.

\section{Metode Pembelajaran di Pondok Pesantren}

Metode pembelajaran di pondok pesantren menurut Imron Arifin (Arifin, 1993) sebagai berikut;

1. Metode musyawarah adalah suatu kegiatan berlatih bercakap-cakap dengan bahasa Arab yang diwajibkan pesantren kepada santri selama mereka tinggal di pondok.

2. Metode Mudhakarah, merupakan suatu penemuan ilmiah yang secara spesifik membahas masalah diniyah seperti aqidah, ibadah, dan masalah agama pada umumnya. Aplikasi metode ini dapat membangkitkan semangat intelektual santri.

3. Metode Majelis Ta'lim, merupakan suatu metode dalam menyampaikan ajaran Islam yang bersifat umum dan terbuka, yang dihadiri jama'ah yang memiliki berbagai latar belakang pengetahuan, tingkat usia, dan jenis kelamin".

4. Metode Wetonan: pembelajaran yang dilaksanakan dengan jalan kyai membaca kitab dalam waktu tertentu dan santri dengan membawa kitab yang sama untuk mendengarkan dan menyimak bacaan kyai. Dalam metode semacam ini tidak dikenal absensinya. Artinya, santri boleh datang boleh tidak, juga tidak ada ujian.

5. Metode Bandongan, yaitu seorang santri tidak harus menunjukan bahwa ia mengerti pelajaran yang sedang dihadapi. Para kyai biasanya membaca dan menerjemahkan kata-kata yang mudah. Penerapan metode tersebut mengakibatkan santri bersikap pasif, sebab kreatifitas dalam proses belajar mengajar didominasi ustadz atau kyai, sementara santri hanya mendengarkan dan memperhatikan

6. Metode Sorogan adalah metode mengaji dengan cara santri menghadap guru seorang demi seorang dengan membawa kitab yang akan dipelajari. Atau sorogan adalah sebuah sistem belajar di mana para 
santri maju satu persatu untuk membaca dan menguraikan isi kitab di hadapan seorang guru atau kyai.

\section{Zakat}

Kata zakat berasal dari Bahasa Arab, yang berarti suci, berkah, tumbuh, dan terpuji. Menurut terminologi zakat merupakan harta tertentu yang telah mencapai syarat tertentu yang diwajibkan oleh Allah SWT untuk dikeluarkan dan diberikan kepada orang yang berhak menerimanya dengan persyaratan tertentu pula.

Menurut Sayyid Sabiq (Sabiq, 2013) zakat adalah hak Allah berupa harta yang diberikan oleh seseorang (yang kaya) kepada orang-orang fakir. Harta itu disebut dengan zakat karena di dalamnya terkandung penyucian jiwa, pengembangannya dengan kebaikan-kebaikan, dan harapan untuk mendapat berkah. Hal itu dikarenakan asal kata zakat adalah az-zakah yang berarti tumbuh, suci, dan berkah.

\section{Dasar Hukum Zakat}

1). Al-Qur'an surat At-Taubah ayat 103: 1.

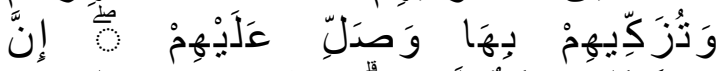

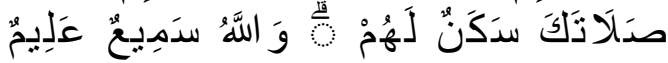
Artinya: "Ambillah zakat dari harta mereka, guna membersibkan dan mensucikan mereka. Dan berdoalab untuk mereka. Sesunggubnya doamu itu (menumbubkan) ketentraman jiwa bagi mereka. Allah Maha Mendengar, Maha Mengetabui”. (Q.S. At-Taubab: 103)

2). Hadits Nabi nomor 492:

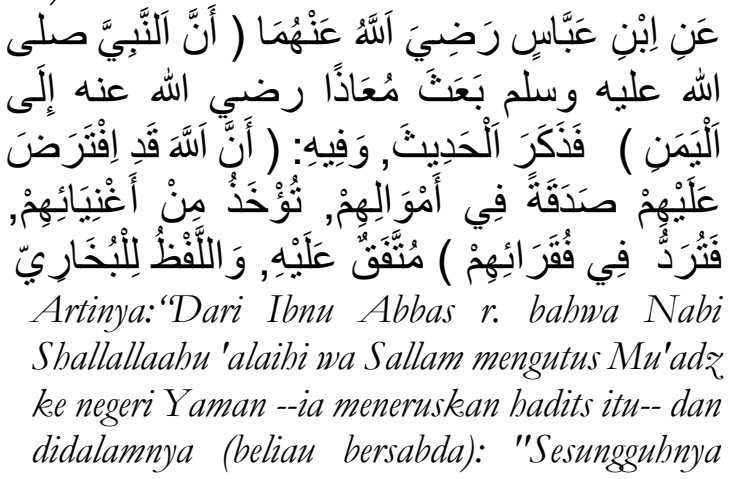

Allah telah mewajibkan mereka zakat dari harta mereka yang diambil dari orang-orang kaya di antara merek a dan dibagikan kepada orang-orang fakir di antara mereka. [3]" Muttafaq Alaibi dan lafadznya menurut Bukbari.[4]

\section{Syarat dan Rukun Zakat}

Syarat-syarat zakat yaaitu sebagai berikut: a). Islam., b). Berakal dan baligh, c. Telah mencapai nishab, d. Merdeka, e). Mencapai haul, f. Kepemilikan yang penuh / sempurna, g. Barangnya produktif atau bisa diproduktifkan, h. Selamat dari hutang / bebas hutang (aslamah minaddaini)

Sedangkan rukun zakat menurut Shahih Muslim (1997:134) adalah mengeluarkan sebagian dari nishab (harta) dengan melepaskan kepemilikan terhadapnya, menjadikannya sebagai milik orang fakir, dan menyerahkannya kepadanya atau harta tersebut diserahkan kepada wakilnya, yakni imam atau orang yang bertugas untuk memungut zakat.

\section{Tujuan Zakat}

Menurut (Sartika, 2008), zakat memiliki tujuan antara lain :

1. Mengangkat derajat fakir - miskin dan membantunya keluar dari kesulitan hidup serta penderitaan.

2. Membantu memecahkan permasalahan yang dihadapi oleh para mustahiq.

3. Membentangkan dan membina tali persaudaraan sesama umat muslim dan manusia pada umumnya.

4. Menghilangkan sifat kikir pemilik harta.

5. Membersihkan sifat dengki dan iri (kecemburuan sosial) dari hati orangorang miskin.

6. Menjembatani jurang pemisah antara yang kaya dengan yang miskin dalam suatu masyarakat.

7. Mengembangkan rasa tanggungjawab sosial pada diri seseorang, terutama pada mereka yang mempunyai harta. Mendidik manusia untuk disiplin menunaikan kewajiban dan 
menyerahkan hak orang lain yang ada padanya.

\section{Golongan yang Berhak Menerima Zakat} (Mustahiq)

Golongan yang berhak menerima zakat ada delapan golongan (asnaf tsamaniyah) seperti Al Qur'an surat At-Taubah ayat 60 yaitu; fakir, miskin, amil zakat, muallaf, memerdekakan budak belian, gharimun, mujahidin dan ibnu sabil.

\section{Pajak Penghasilan (PPh).}

Pajak penghasilan lebih dikenal dengan Pajak Penghasilan (PPh) Pasal 25 atau PPh 25 merupakan pajak yang dibebankan pada penghasilan perorangan, perusahaan atau badan hukum lainnya.

\section{Subjek Pajak}

Subjek pajak penghasilan (PPh) menurut Undang-Undang Nomor 36 Tahun 2008 Pasal 2 adalah sebagai berikut:

1. Subjek pajak pribadi yaitu orang pribadi yang bertempat tinggal di Indonesia, orang pribadi yang berada di Indonesia lebih dari 183 (seratus delapan puluh tiga) hari dalam jangka waktu 12 (dua belas) bulan, atau orang pribadi yang dalam suatu tahun pajak berada di Indonesia dan mempunyai niat untuk bertempat tinggal di Indonesia.

2. Subjek pajak harta warisan belum dibagi yaitu warisan dari seseorang yang sudah meninggal dan belum dibagi tetapi menghasilkan pendapatan, maka pendapatan itu dikenakan pajak.

3. Subjek pajak badan, yaitu badan yang didirikan atau bertempat kedudukan di Indonesia, kecuali unit tertentu dari badan pemerintah yang memenuhi kriteria berikut; a). Pembentukannya berdasarkan ketentuan peraturan perundang-undangan; b).Pembiayaanya bersumber dari Anggaran Pendapatan dan Belanja Negara atau Anggaran Pendapatan dan Belanja Daerah; c). Penerimaannya dimasukkan dalam anggaran Pemerintah Pusat atau
Pemerintah Daerah; d). Pembukuannya diperiksa oleh aparat pengawasan fungsional negara;

4. Bentuk usaha tetap yaitu bentuk usaha yang digunakan oleh orang pribadi yang tidak bertempat tinggal di Indonesia atau berada di indonesia tidak lebih dari 183 hari dalam jangka waktu dua belas bulan, atau badan yang tidak didirikan dan berkedudukan di Indonesia, yang melakukan kegiatan di Indonesia.

\section{Bukan Subjek Pajak}

Orang atau badan yang tidak termasuk subjek pajak Undang-Undang Nomor 36 Tahun 2008 Pasal 3 sebagai berikut:

1. Badan perwakilan negara asing;

2. Pejabat perwakilan diplomatik dan konsulat atau pejabat - pejabat lain dari negara asing dan orang - orang yang diperbantukan kepada mereka yang bekerja pada dan bertempat tinggal bersama mereka dengan syarat bukan warga negara indonesia dan negara yang bersangkutan memberikan perlakuan timbal balik;

3. Organisasi internasional yang ditetapkan oleh keputusan menteri keuangan dengan syarat Indonesia ikut dalam organisasi tersebut dan organisasi tersebut tidak melakukan kegiatan usaha di Indonesia. Contoh: WTO, FAO, UNICEF; dan

4. Pejabat perwakilan organisasi internasional yang ditetapkan oleh keputusan menteri keuangan dengan syarat bukan warga negara indonesia dan tidak memperoleh penghasilan dari Indonesia;

\section{Objek Pajak}

Yang dimaksud dengan objek pajak penghasilan yaitu setiap tambahan kemampuan ekonomis yang diterima atau diperoleh wajib pajak, baik yang berasal dari Indonesia maupun dari luar Indonesia, yang dapat dipakai untuk konsumsi atau untuk menambah kekayaan wajib pajak yang 
bersangkutan, dengan nama dan dalam bentuk apapun.

\section{METODOLOGI PENELITIAN}

Pendekatan yang digunakan dalam penelitian ini adalah pendekatan kualitatif, dikarenakan penelitian ini lebih menekankan pada aspek proses dan melibatkan kerja lapangan.

Pengumpulan data yang dipergunakan adalah observasi, wawancara, dokumentasi. Tahapan analisis data melalui pengumpulan data, reduksi data, penyajian data dan penarikan kesimpulan/verifikasi.

Penelitian ini termasuk dalam penelitian deskriptif. Menurut (Moleong, 2017) penelitian deskriptif adalah penelitian yang berupaya mengungkapkan suatu masalah dan keadaan sebagaimana adanya, untuk itu peneliti dibatasi hanya mengungkapkan fakta-fakta dan tidak menggunakan hipotesa. Penelitian deskriptif bertujuan untuk menggambarkan secara tepat sifat individu dan keadaan sosial yang timbul di masyarakat untuk dijadikan sebagai obyek penelitian.

Tahapan dalam penelitian ini yaitu; 1 ). Pra Penelitian/ Studi Pendahuluan, 2). Merumuskan dan pembatasan masalah, 3). Melakukan studi kepustakaan/ literature, 4). Menentukan desaian dan metode penelitian 5). Mengumpulkan dan menganalisis data. 6). Menyajikan hasil dan membuat kesimpulan.

Hasil dari analisis data kemudian ditampilkan dalam bentuk tabel, profil dan lain sebagainya. Kemudian peneliti menarik kesimpulan dari hasil penelitian tersebut sebagai interpretasi hasil temuan penelitian. Selanjutnya, peneliti memberi saran kepada pihak-pihak yang terkait berdasarkan hasil penelitian tersebut.

Penelitian ini bertempat di tiga Pondok Pesantren Salaf yang berada di Jawa Tengah yaitu; 1). Pondok Pesantren Al Maslahah alamat Dukuh Malangan Desa Trimulyo Kecamatan Kayen Kabupaten Pati (bagian Timur), 2). Pondok Pesantren Al Inayah, Desa Wareng Kecamatan Tempuran
Kabupaten Magelang (bagian Tengah), 3). Pondok Pesantren Darussalam, Desa Dukuhwaluh Kecamatan Kembaran Kabupaten Banyumas (bagian Barat)

Fokus dalam penelitian;

1. Adanya dualisme pemungutan (double taxs) untuk orang muslim, di mana seorang wajib pajak (taxs payers) juga seorang wajib zakat (murzaki).

2. Keinginan umat muslim dalam menjalankan kewajiban zakat atas perintah agama dan menjalankan kewajiban membayar zakat sebagai warga Negara, 3). Pandangan hukum dari para Kyai pengasuh Pondok Pesantren Salaf di Jawa Tengah tentang pembayaran zakat yang dapat berfungsi sebagai pengurang pajak penghasilan,

Penelitian ini sangat penting karena masyarakat muslim masih ragu untuk menerima hukum bahwa dengan berzakat dapat berfungsi sebagai pengurang pajak penghasilan. Satu sisi masyarakat muslim merasa keberatan dengan adanya pengeluaran ganda di mana seorang muslim wajib membayar pajak dan juga seorang wajib mengeluarkan zakat tersebut, padahal umat muslim ingin menjalankan kewajiban zakat atas perintah agama dan menjalankan kewajiban membayar zakat sebagai warga negara. Sehingga melalui penelitian ini diharapkan dapat dihasilkan kepastian hukum tentang pembayaran zakat yang dapat berfungsi sebagai pengurang pajak penghasilan.

\section{HASIL DAN PEMBAHASAN}

\section{Perspektif Kyai Pondok Pesantren Salaf di Jawa Tengah Mengenai Zakat dapat Berfungsi sebagai Pengurang Pajak Penghasilan}

Zakat merupakan bentuk ibadah maaliyah ijtima'iyyah yaitu bentuk ibadah yang bersentuhan langsung dengan perekonomian keuangan kemasyarakatan dan menempati tempat yang sangat strategis serta menjadi penentu bagi kesejahteraan umat baik dari segi pembangunan maupun dari ajaran Islam 
itu sendiri. Secara umum, kyai-kyai di pondok pesantren salaf di Jawa Tengah sepakat mengenai zakat dapat berfungsi sebagai pengurang pajak penghasilan, dikarenakan zakat profesi atau penghasilan (al-mal-al-mustafad) merupakan zakat yang dapat dibebankan kepada setiap keahlian atau pekerjaan yang sifatnya profesionalitas tertentu, sama juga pekerjaan tersebut dikerjakan secara sendiri ataupun pekerjaan tersebut dilakukan secara bersama-sama dengan orang lain maupun organisasi dan lembaga yang dapat menghasilkan uang (penghasilan) yang halal serta sudah mencapai batas minimal wajib zakat (nishab). Misalnya; dokter, PNS, dosen, advokat, pejabat, konsultan, pegawai swasta dan lainlain.

Di kalangan Kyai Pondok Pesantren Salaf di Jawa Tengah menyatakan bahwa berdasarkan pendapat ulama ahli fiqih, hukum tentang mengeluarkan zakat penghasilan atau zakat profesi saling berbeda pendapat. Bagi kalangan ulama mazhab al arba'ab secara mayoritas tidak diwajibkan mengeluarkan zakat profesi atau penghasilan saat gaji tersebut diterima, kecuali apabila sudah tercapai batas minimum untuk wajib zakat (nishab) dan mencapai waktu satu tahun (haul).

Namun berdasarkan pendapat hasil kajian majma' fiqh, para ulama pada zaman mutaakhirin seperti Syekh Yusuf Al Qardlowi, Syekh Muhammad Abu Zahro, Syekh Abdurrahaman Hasan, Syekh Abdul Wahab Khallaf dan Syekh Wahbah Az-Zuhaili dan berdasarkan fatwa Majelis Ulama Indonesia (MUI) No. 3 Tahun 2003 menyatakan bahwa mengeluarkan zakat profesi atau penghasilan adalah wajib hukumnya.

Keputusan ini berpedoman kepada hujjah sahabat nabi, antara lain; Ibnu Mas'ud, Ibnu Abbas dan Muawiyah, pendapat para tabiin seperti Al-Hasan Al Basri, Az-Zuhri, Makhul dan pendapat dari Umar bin Abdul Aziz serta pendapat beberapa ulama fiqh yang lain dan berdasarkan QS Al-Baqarah: 267 :
"... Ambilah olehmu zakat dari sebagian harta mereka, dengan zakat itu kamu membersibkan dan mensucikan mereka..." (QS. At-Taubah 9:103) dan firman Allah SWT: "Hai orang-orangyang beriman, nafkabkanlah sebagian dari hasil usabamu yang baik-baik..." (QS. Al-Baqarah. 2:267)

Keterangan di dalam ayat tersebut disebutkan bahwa umat Islam wajib mengeluarkan zakat sebanyak 2,5\% yang berasal dari jumlah keseluruhan (total) dari penghasilan yang mereka peroleh, yang diperuntukkan bagi absnaf tsamaniyah (delapan golongan yang mempuyai hak untuk menerima zakat). Kewajiban membayar zakat penghasilan bagi umat Islam sebesar 2,5\% tersebut, apabila penghasilan mereka dalam satu tahun bisa mencapai nishab. Nisab bagi muslim yang bisa dikenai pajak penghasilan adalah bagi mereka yang dalam waktu setahun sudah berpenghasilan sama dengan nilainya 85 gr emas murni. Sedangkan bagi umat Islam yang dalam satu tahun berpeghasilan sebesar niali 85\% emas murni, maka tidak dikenakan zakat penghasilan.

Serta berdasarkan hadits shahih yang diriwayatkan oleh Imam Tirmidzi, Rasulullah berkata:

"Keluarkanlah olehmu sekalian zakat dari harta kamu sekalian," dan hadits dari Abu Hurairah r.a. Rasulullah SAW bersabda: "Sedekah hanyalab dikelaurkan dari kelebihan/kebutuban. tangan atas lebih baik daripada tangan dibawah. mulailah (dalam membelanjakan harta) dengan orang yang menjadi tanggung jawabmu." ( HR. Ahmad)

\section{Tata Cara Mengeluarkan Zakat Profesi atau Penghasilan}

Kyai Pondok Pesantren Salaf di Jawa Tengah berpendapat bahwa tata cara mengeluarkan zakat penghasilan atau profesi bisa mengikuti pendapat Dr. Yusuf Qardlawi yaitu sebagai berikut. 


\section{Pengeluaran Bruto.}

Yang dimaksud dengan pengeluaran bruto adalah membayar zakat berdasarkan penghasilan kotor, yaitu; mengeluarkan zakat profesi atau penghasilan yang sudah tercapai nishabnya yang disetarakan dengan $85 \mathrm{gr}$ emas dalam jumlah satu tahun dan dikeluarkan zakat sebesar 2,5\% secara seketika pada waktu menerima gaji atau penghasilan dan belum dikurangi beban apapun.

Contoh; Apabila seseorang dalam satu bulan mendapatkan gaji atau penghasilan sebesar Rp 2.000.000, maka jika dikeluarkan zakat secara langsung setiap bulan, cara menghitungnya yaitu; Rp $2.000 .000 \times 2,5 \%=$ Rp 50.000. Dan apabila dibayar di akhir tahun sebesar Rp 50.000 x $12=$ Rp 600.000 .

Pengeluaran bruto ini berdasarkan pendapat Imam 'Auza'i dan Imam Az-Zuhri, yaitu; "bila seseorang memeperoleh penghasilan dan ingin membelanjakannya sebelum bulan wajib zakat datang, maka hendaknya ia segera mengeluarkan zakat itu terlebih dahulu dari membelanjakannya". Hal ini diqiyaskan dengan harta zakat lainnya yang secara langsung dapat dikeluarkan zakatnya dan tidak perlu dikurangi pengeluaran apapun. Contoh; zakat emas, perak, ternak, rikaz dan ma'dzan.

\section{Pengeluaran Netto (zakat bersih).}

Artinya, mengeluarkan zakat penghasilan atau profesi yang sudah tercapai nishabnya sesudah terkurangi pengeluaran kebutuhan hidup (pokok) sehari-hari, berupa papan, pangan, sandang, dan hutang serta kebutuhan hidup sehari-hari lainnya yang digunakan untuk keperluan hidupnya, keluarganya dan orang-orang yang menjadi tanggungan akan kebutuhan hidupnya.

Contoh; Apabila jumlah penghasilan seseorang dalam satu tahun dan sesudah terkurangi kebutuhan sehari-hari (pokok) dan masih mencapai nishabnya, maka penghasilan orang tersebut harus (wajib) dizakati. Tetapi jika penghasilan orang tersebut setelah dikurangi kebutuhan pokok ternyata tidak memenuhi nishab, maka orang tidak wajib untuk mengeluarkan zakat. Hal ini disebabkan karena orang tersebut tidak masuk dalam golongan orang yang wajib zakat (muzakki), akan tetapi orang tersebut masuk golongan orang berhak penerima zakat (mustahiq), disebabkan orang tersebut telah berubah menjadi orang tidak mampu (miskin) karena penghasilanya tidak cukup untuk menopang kebutuhan pokok hidup sehari-hari. Sesuai dengan Hadist Nabi riwayat Imam Al-Bukhori dari Hakim bin Hizam bahwa Rosulullah SWA bersabda;

".... dan paling baiknya zakat itu dikeluarkan dari kelebihan kebutuban...".

\section{Dipotong Operasional Kerja.}

Artinya, apabila seseorang sesudah menerima penghasilan atau gaji serta sudah tercapai nishabnya, maka gaji atau penghasilannya langsung dipotong dahulu dengan biaya operasional kerja tersebut.

Contoh; Apabila ada seseorang setiap bulan menerima gaji atau penghasilan sebesar Rp 3.000.000. Setelah terkurangi biaya untuk transport dan untuk biaya makan setiap hari dia bekerja sebesar Rp 600.000 dan tersisa $\mathrm{Rp}$ 2.400.000. Oleh sebab itu zakat yang wajib keluar sebesar Rp 2.400.000 $x 2,5 \%=\operatorname{Rp} 60.000$.

Hal ini dinisbatkan pada pendapat Imam Atho' dan lain-lain dalam masalah zakat dari hasil bumi seperti jagung, kurma, padi, gandum dan lain-lain. Biaya dikeluarkan terlebih dahulu daripada hasil buminya seperti kurma, padi dan sejenisnya lebih dahulu, kemudian zakat baru dikeluarkan dari sisanya. Contoh; Adanya perbedaan presentasi antara zakat hasil bumi yang dialiri memakai air hujan sebesar 10\% dan yang dialiri dengan air irigasi sebesar 5\%.

Pendapat Dr. Yusuf Qardlawi tersebut di atas dapat disimpulkan bahwa gaji atau penghasilan halal seseorang yang sudah mencapai nishab-nya seberat 85 gram emas, maka harus (wajib) dikeluarkan zakatnya $2,5 \%$ dari harga jual emas seberat 85 gr tersebut, di setiap bulan maupun di setiap akhir tahun. Mengeluarkan zakat yang lebih utama (afdlal) adalah jika dikeluarkan dari penghasilan atau gaji kotor sebelum 
dikurangi pengeluaran yang lainnya. Hal ini dikhawatirkan apabila ada harta benda yang sudah wajib dizakati namun tidak dizakati.

Tetapi secara umum, walaupun kyaikyai pondok pesantren salaf di Jawa Tengah sepakat jika zakat bisa berfungsi sebagai pengurang pajak penghasilan, namun beliaubeliau menyarankan supaya dana zakat tersebut lebih banyak memberi manfaat dan kemaslahatn kepada umat Islam secara umum, baik untuk jangka pendek, menengah dan panjang. Maka alangkah baiknya jika dana zakat tersebut bisa dialihkan dengan model zakat produktif dan dalam mengelola zakat menggunakan manajemen zakat yang transparan, akuntabel dan profesional.

\section{Zakat Produktif}

Zakat yang dikeluarkan oleh umat Islam jangan sampai hanya bersifat konsumtif, artinya zakat yang dikeluarkan itu langsung habis hanya untuk kepentinga konsumsi belaka. Akan tetapi zakat dapat dikembangkan lagi untuk kemaslahatan umat yang lebih bermanfaat, baik dalam jangka pendek, jangka menengah ataupun jangka panjang. Salah satu usaha untuk mengembangkan zakat tersebut lebih bermanfaat baik dalam jangka pendek, jangka menengah ataupun jangka panjang perlu dikembangkan dengan model zakat produktif, artinya dengan dari harta zakat tersebut mampu memberdayakan dan meningkatkan kemandiriian ekonomi bagi kalangan fakir miskin (ashnaf tsamaniyah) maupun golongan lain yang membutuhkan. Sehingga kaum fakir miskin (ashnaf tsamaniyah) maupun golongan lain yang membutuhkan benar-benar dapat mandiri dengan bantuan zakat tersebut. Maka, apabila pengembangan zakat produktif ini benar-benar dapat terealisasi dan dapat dilakukan oleh umat Islam dengan cara yang profesional maka fakir miskin (ashnaf tsamaniyah) maupun golongan lain yang membutuhkan tadi bisa mandiri dari segi ekonomi dan bahkan yang semula sebagai penerima zakat (mustahiq) akhirnya bisa menjadi pemberi zakat (murakei).
Zakat produktif yang dikembangkan oleh umat Islam supaya benar-benar bisa berimplikasi uutuk kemaslahan umat, maka bisa dilakukan dengan beberapa cara, antara lain yaitu;

a. Zakat dijadikan sebagai investasi produktif.

Zakat yang sudah terkumpul di lembaga pengumpul zakat baik BAZNAS, LAZ, BAZIS dan lain sebagainya maupun yang masih di perseorangan maupun kelompok dapat dijadikan sebagai investasi yang produktif, namun harus dengan minta ijin dan ridla kepada orang yang berhak menerima zakat (mustahiq) . Tetapi apabila orang yang berhak menerima zakat (mustabiq) tersebut tidak mengijinkan maka tidak boleh dilakukan.

b. Memberikan Modal Kerja Bagi Mustabiq.

Uang zakat supaya menjadi lebih produktif dan menjadi lebih bermanfaat bagi kepentingan dan kemaslahatan umat Islam, maka dapat dikembangkan dengan jalan memberi modal produktif kepada orang yang berhak menerima zakat (muzakki), baik berupa modal uang maupun modal barang dan jasa. Bahkan supaya orang yang berhak menerima zakat (muzakki) tersebut jika pada suatu saat menerima zakat dengan modal produktif tidak sia-sia, maka sebaiknya mereka diberi juga ilmu pengetahuan yang sesuai dengan jenis modal produktif yang dikehendaki oleh pemberi zakat. Artinya, jika seseorang itu diberi zakat dengan zakat produktif, maka di samping orang itu diberi uang zakat, maka orang tersebut juga diberi ilmu pengetahuan seperti training, kursus, pelatihan-pelatihan kerja, Balai Latihan Kerja (BLK) dan sebagainya.

c. Mengambil Hutang

Artinya, melakukan usaha-usaha produktif dengan cara mengambil hutang terlebih dahulu, kemudian orang yang berhutang (gharim) tersebut berhak menerima zakat untuk melunasi hutang-hutangnya atas nama orang yang berhutang (gharim) tetapi dengan syarat bahwa hutangnya tersebut benar-benar untuk kemashlahatan umum (maslahah lil 'ammah). Adapun cara yang 
nomor tiga ini dapat ditempuh untuk hal-hal yang betul-betul menjadi kebutuhan umum, misalnya tempat berobat khusus fakirmiskin.

\section{Manajemen yang Transparan, Akuntabel dan Profesional}

Transparansi merupakan sesuatu hal yang terbuka, jelas, nyata serta dapat dipertanggungjawabkan akan keberadaannya. Salah satu cara supaya berhasil dalam mengelola uang zakat adalah harus mengutamakan transparansi manajemen. Karena dengan menerapkan transparansi manajemen tersebut, maka tidak ada sesuatu hal yang tersembnyi di dalamnya, sehingga tersedia informasi yang lengkap untuk keperluan kerja sama, kolaborasi, dan pengambilan keputusan yang bersifat kolektif dalam penanganan alur keuangan zakat. Maka dalam pengelolaan uang zakat diperlukan suatu bentuk manajeman yang benar-benar transparan, sehingga tidak ada kecurigaan.

\section{Transparansi Manajemen}

Dalam mengelola keuangan zakat sangat diperlukan adanya transparansi manajemen. Hal ini diperlukan karena untuk menjaga siklus kerja sama yang sehat di dalam lembaga keuangan yang menangani zakat tersebut. Adapun tujuan dari transparansi manajemen antara lain mencegah nepotisme dan meminimalisir adanya tenaga kerja atau bidang yang tidak potensial dalam lembaga pengelola zakat

\section{Transparansi Keuangan}

Transparansi keuangan merupakan salah satu perkara yang amat urgen dalam lembaga keuangan pengelola zakat . Karena keuangan adalah sektor paling rawan dan memungkinkan terjadi penyelewengan. Tujuan transparansi keuangan adalah untuk menghindari timbulnya korupsi dan menjaga kepercayaan beberapa pihak yang berkepentingan dalam lembaga pengelola keuangan.

Dalam pengelolaan keuangan zakat harus akuntabel merupakan suatu istilah untuk merealisasikan pertanggungjawaban seseorang atau lembaga tertentu yang berkaitan dengan sistem administrasi. Pengelola zakat dan penerima zakat harus bisa saling bertanggung jawab terhadap sesama dan terhadap Allah Swt.

Defisi profesional adalah seseorang yang dapat menjalankan profesinya sesuai dengan keahlian yang dimilikinya. Maka di dalam melakukan tugas profesi sebagai pengelola zakat, seseorang yang profesional harus bisa bersikap yang objektif, artinya orang tersebut harus bebas dari rasa benci, sentimen, rasa malas, malu, ogah bertindak untuk mengambil keputusan.

\section{Mekanisme Zakat Berfungsi sebagai Pengurang Pajak Penghasilan (PPh)}

Bagi kaum muslim yang membayar zakat dapat berfungsi sebagai Pengurang Pajak Penghasilan (PPh) sebagaimana yang diatur dalam UU No. 38 Tahun 1999 tentang Pengelolaan Zakat, yang kemudian diperkuat lagi dengan UU Zakat yang terbaru yaitu UU No. 23 Tahun 2011 tentang Pengelolaan Zakat.

Sedangkan latar belakang dari zakat dapat berfungsi sebagai Pengurang Pajak Penghasilan $(\mathrm{PPh})$ tersebut dijelaskan dalam penjelasan Pasal 14 ayat (3) UU 38 Tahun 1999 bahwa pengurangan zakat dari laba atau pendapatan sisa kena pajak adalah dimaksudkan agar wajib pajak tidak terkena beban ganda, yakni kewajiban membayar zakat sebagai seorang muslim dan dan kewajiban membayar pajak sebagai warga negara. Ketentuan ini juga masih diatur dalam Undang-Undang yang terbaru yaitu UU 23 Tahun 2011, Pasal 22 yang bunyinya:

"Zakat yang dibayarkan oleh muzakki kepada $B A Z N A S$ atau LAZ dikurangkan dari penghasilan kena pajak."

Kemudian dipertegas lagi pada peraturan perpajakan yang baru sejak disahkannya Undang-Undang Nomor 17 Tahun 2000 tentang perubahan ketiga atas Undang-Undang Nomor 7 Tahun 1983 tentang Pajak Penghasilan (PPh), yang 
diatur pada Pasal 4 ayat (3) huruf a nomor 1 yang berbunyi:

"Yang tidak termasuk sebagai Objek Pajak adalab: bantuan sumbangan, termasuk zakat yang diterima oleh badan amil rakat atau lembaga amil rakat yang dibentuk atau disabkan oleh Pemerintab dan para penerima zakat yang berhak."

Di dalam pasal tersebut, baru dimuat secara jelas bahwa yang tidak masuk ke dalam objek pajak yaitu zakat. Sebaliknya, pada UU tersebut belum mengatur pengurangan pajak atas kewajiban pembayaran sumbangan untuk agama lain, sehingga dapat menimbulkan potensi kecemburuan sosial antar agama di Indonesia. Maka dengan diterbitkannya Undang-Undang Nomor 36 Tahun 2008 tentang perubahan keempat atas UndangUndang Nomor 7 Tahun 1983 tentang Pajak Penghasilan, maka bunyi pasal itu berubah, yaitu:

"Yang dikecualikan dari objek pajak adalab:bantuan atau sumbangan, termasuk rakat yang diterima oleb badan amil zakat atau lembaga amil zakat yang dibentuk atau disabkan oleb pemerintah dan yang diterima oleh penerima zakat yang berhak atau sumbangan keagamaan yang sifatnya wajib bagi pemeluk agama yang diakui di Indonesia, yang diterima oleh lembaga keagamaan yang dibentuk atau disabkan oleh pemerintah dan yang diterima oleb penerima sumbangan yang berbak, yang ketentuannya diatur dengan atau berdasarkan Peraturan Pemerintah."

Ketetapan yang sama juga diatur pula pada UU Pajak Penghasilan Pasal 9 ayat (1). Selain itu dalam PP No. 60 Tahun 2010 Pasal 1 Ayat (1) yang mengatur perkara zakat atau sumbangan keagamaan yang sifatnya wajib yang diperbolehkan dikurangkan dari penghasilan bruto juga menyatakan:

"Zakeat atau sumbangan keagamaan yang sifatnya wajib yang dapat dikurangkan dari penghasilan bruto meliputi:

a). Zakat atas penghasilan yang dibayarkan oleh Wajib Pajak orang pribadi pemeluk agama Islam dan/atau oleb Wajib Pajak badan dalam negeri yang dimiliki oleh pemeluk agama Islam kepada badan amil zakat atau lembaga amil zakat yang dibentuk atau disabkan oleb Pemerintab; atau b). Sumbangan keagamaan yang sifatnya wajib bagi Wajib Pajam negeri yang dimiliki oleb pemeluk agama selain agama Islam, yang diakui di Indonesia yang dibayarkan kepada lembaga keagamaan yang dibentuk atau disabkan oleh Pemerintah."

Selanjutnya, lembaga atau badan yang disahkan pemerintah sebagai penerima sumbangan keagamaan atau zakat yang bersifat wajib yang bisa dikurangkan dari penghasilan bruto ditetapkan pada Peraturan Direktur Jenderal Pajak No. PER33/PJ/2011, yang berjumlah 21 badan/ lembaga antara lain: Badan Amil Zakat Nasional (BAZNAS), LAZ Yayasan Rumah Zakat Indonesia, LAZ Dompet Dhuafa Republika, Badan Dharma Dana Nasional Yayasan Adikara Dharma Parisad (BDDN YADP), Lembaga Sumbangan Agama Kristen Indonesia (LEMSAKTI). Kemudian dipertegas lagi pada Peraturan Direktur Jenderal Pajak Nomor PER-15/PJ/2012 dan berlaku mulai tanggal 11 Juni 2012.

\section{Mekanisme Zakat Berfungsi sebagai Pengurang Pajak Penghasilan (PPh).}

Dalam Peraturan Dirjen Pajak No. PER-6/PJ/2011 Tahun 2011 tentang Pelaksanaan Pembayaran dan Pembuatan Bukti Pembayaran atas Zakat atau Sumbangan Keagamaan yang Sifatnya Wajib yang Dapat Dikurangkan dari Penghasilan Bruto dapat ditemui tentang mekanisme pengurangan zakat dari penghasilan bruto, yaitu;

\section{Pasal 2}

(1). Wajib Pajak yang melakukan pengurangan zakat atau sumbangan keagamaan yang sifatnya wajib sebagaimana dimaksud dalam Pasal 1, wajib melampirkan fotokopi bukti pembayaran pada Surat Pemberitahuan (SPT) Tahunan Pajak Penghasilan Tahun Pajak dilakukannya pengurangan zakat atau sumbangan keagamaan yang sifatnya wajib.

(2). Bukti pembayaran sebagaimana dimaksud pada ayat (1) :

a. dapat berupa bukti pembayaran secara langsung atau melalui transfer rekening 
bank, atau pembayaran melalui Anjungan Tunai Mandiri (ATM), dan

b. paling sedikit memuat:

1) Nama lengkap Wajib Pajak dan Nomor Pokok Wajib Pajak (NPWP) pembayar;

2). Jumlah pembayaran;

3). Tanggal pembayaran;

4). Nama badan amil zakat; lembaga amil zakat; atau lembaga keagamaan yang dibentuk atau disahkan Pemerintah; dan

5). Tanda tangan petugas badan amil zakat; lembaga amil zakat; atau lembaga keagamaan, yang dibentuk atau disahkan Pemerintah, di bukti pembayaran, apabila pembayaran secara langsung; atau

6). Validasi petugas bank pada bukti pembayaran apabila pembayaran melalui transfer rekening bank.

\section{Pasal 3}

Zakat atau sumbangan keagamaan yang sifatnya wajib tidak dapat dikurangkan dari penghasilan bruto apabila :

a. tidak dibayarkan oleh Wajib Pajak kepada badan amil zakat; lembaga amil zakat; atau lembaga keagamaan, yang dibentuk atau disahkan Pemerintah; dan/atau

b. bukti pembayarannya tidak memenuhi ketentuan sebagaimana dimaksud dalam Pasal 2 ayat (2).

\section{Pasal 4}

(1). Pengurangan zakat atau sumbangan keagamaan yang sifatnya wajib sebagaimana dimaksud dalam Pasal 1 dilaporkan dalam Surat Pemberitahuan (SPT) Tahunan Pajak Penghasilan Wajib Pajak yang bersangkutan dalam Tahun Pajak dibayarkan zakat atau sumbangan keagamaan yang sifatnya wajib tersebut.

(2). Dalam Surat Pemberitahuan (SPT) Tahunan Pajak Penghasilan, zakat atau sumbangan keagamaan yang sifatnya wajib sebagaimana ayat (1) dilaporkan untuk menentukan penghasilan neto.

Berdasarkan keterangan di atas, maka pengeluaran zakat bisa berfungsi mengurangi beban pajak penghasilan. Hal ini dikarenakan zakat diperkecualikan dari objek pajak yang lainnya.

Keberlakuan pengurangan pajak penghasilan ini diberlakukan juga pada sumbangan wajib keagamaan untuk pemeluk agama selain Islam yang diakui di Indonesia. Sumbangan tersebut diterimakan kepada lembaga keagamaan yang sudah ditetapkan dan disahkan pemerintah serta diterima oleh orang yang berhak menerimanya sesuai ketentuan yang diatur dalam Peraturan Pemerintah.

\section{KESIMPULAN}

Penelitian ini menunjukkan bahwa secara umum perspektif Kyai Pondok Pesantren Salaf di Jawa Tengah sepakat jika zakat yang dibayarkan oleh umat Islam lewat BAZNAS dapat berfungsi sebagai pengurang Pajak Penghasilan (PPh), karena zakat penghasilan atau profesi (al-mal-almustafad) merupakan zakat yang dapat dikenakan kepada setiap pekerjaan atau keahlian yang sifatnya profesionalitas tertentu, baik pekerjaan tersebut dilakukan secara sendiri maupun dilakukan secara bersama-sama dengan orang lain maupun lembaga lain yang dapat mendatangkan penghasilan (uang) yang halal serta sudah mencapai batas minimum, maka wajib mengeluarkan zakat (nishab). Sedangkan penyaluran zakat sebaiknya dialihkan dari bentuk konsumtif ke dalam bentuk produktif. Serta pengelolaan zakat menggunakan manajemen zakat yang transparan, akuntabel dan profesional.

\section{DAFTAR PUSTAKA}

Arifin, I. (1993). Kepemimpinan Kyai Kasus Pondok Pesantren Tebuireng. Malang: Kalimasahada Press.

Doa, M. J. (2008). Membangun Ekonomi Umat melalui Pengelolaan Zakat Harta, Pengumpulan Zakat dengan Sistem Administrasi perpajakan, Menghindari Pungutan Double Zakat dan Pajak. Ciputat: Nuansa Madani. 
Hasbullah. (2001). Sejarah Pendidikan Islam di Indonesia. Jakarta: Raja Grafindo Persada.

Kemendikbud. (2018). Kamus Besar Bahasa Indonesia Edisi Kelima (KBBI V). KBBI Online.

Mas'ud, M. F. (2010). Pajak Itu Zakat: Uang Allab untuk Kemaslabatan Rakyat. Bandung: Mizan Media Utama.

Moleong, L. J. (2017). Metodologi Penelitian Kualitatif (Edisi Revisi). Bandung: Remaja Rosda Karya.

Mulkhan, A. M. (2003). Menggagas Pesantren Masa Depan. Yogyakarta: Qirtas.

Sabiq, S. (2013). Fiqih Sunnah. In Jilid 4, Cetakan II. Jakarta: Tinta Abadi Gemilang.

Sartika, M. (2008). Pengaruh Pendayagunaan Zakat Produktif terhadap Pemberdayaan Mustahiq pada LAZ Yayasan Solo Peduli Surakarta. La_Riba, II(No. 1), 75-89. https://doi.org/10.20885/lariba.vol2.i ss1.art6

UU 38 Tahun 1999 tentang zakat bisa berfungsi sebagai Pengurang Pajak Penghasilan (PPh). (n.d.). Retrieved from

https://www.hukumonline.com/pusat data/detail/28418/nprt/1011/uu-no36-tahun-2008-perubahan-keempatatas-undang-undang-nomor-7-tahun1983-tentang-pajak-penghasilan

UU No. 36 Tahun 2008 tentang Perubahan Keempat atas UU No. 7 Tahun 1983 tentang Pajak Penghasilan. (n.d.). Retrieved from https://www.hukumonline.com/pusat data/detail/28418/nprt/1011/uu-no36-tahun-2008-perubahan-keempatatas-undang-undang-nomor-7-tahun1983-tentang-pajak-penghasilan 